\title{
Analysis of Toxoplasma gondii antigens with sera from toxoplasmosis patients
}

\author{
Análise de antígenos de Toxoplasma gondii em \\ soros de pacientes com toxoplasmose \\ Mario de la Luz Galván-Ramírez, Cecilia Guillén-Vargas, \\ Rafoel Sanvedra-Durán and Alfonso Islas-Rodríguez
}

\begin{abstract}
Some proteins of the Toxoplasma gondii are recognized by $\lg G$, IgM and $\lg A$ antibodies in patients with acute and chronic toxoplasmosis, depending on the strain and stage of the Toxoplasma. Sixty-nine sera from immunocompetent individuals were studied through the WesternBlot Test: 20 has an acute infection, 29 has a chronic toxoplasmosis infection and 20 were healthy (seronegatives). The protein analysis revealed by $\lg G$ and $\lg M$ antibodies were performed through the Immunoplot method in order to know their recognition frequency $(f)$ and be valued as infection markers. In the acute phase, the IgM antibodies showed a recognition frequency $(f=0.60)$ for the $60 \mathrm{kDa}$ protein, and in the chronic phase the IgG antibodies showed a recognition frequency $(f=0.68)$ for the $12 \mathrm{kDa}$ protein. Seronegatives revealed no type of band. The protein of $12 \mathrm{kDa}$ can be a diagnostic marker of the chronic phase while protein 60kDa of the acute phase of toxoplasmosis.
\end{abstract}

Key-words: Toxoplasmosis. Acute. Chronic. Antigen. Toxoplasma gondii.

Resumo Demonstrou-se que algumas proteínas do Toxoplasma gondii são reconhecidas pelos anticorpos IgG, IgM e IgA em pacientes com toxoplasmose aguda e crônica. A cepa e o estágio do protozoário interferem na diferença. Sessenta e nove soros de indivíduos imunocompetentes foram submetidos à pesquisa de anticorpos pela técnica de Western-Blot, sendo 20 dos soros provenientes de pacientes com infecção aguda e 29 de infecção crônica de toxoplasmose e 20 sem doença (soronegativos). A análise das proteínas reveladas pelos anticorpos Ig G e lgM foi feita pelo método de Inmunoplot com a finalidade de se conhecer a freqüência de reconhecimento (f), e serem valorizados como marcadores de infecção. Na fase aguda os anticorpos IgM apresentaram uma freqüência de reconhecimento $(f=0.60)$ para a proteína de $60 \mathrm{kDa}$. Na fase crônica, os anticorpos IgG apresentaram $(f=0.68)$ para a proteína de $12 \mathrm{kDa}$. Soronegativos não revelaram nenhuma informação. A proteína de 12kDa pode ser um marcador diagnóstico da fase crônica, e a proteína de 60kDa pode ser um marcador diagnóstico da fase aguda da toxoplasmose.

Palavras-chaves: Toxoplasmose. Aguda. Crônica. Antígeno. Toxoplasma gondii.

Address to: Dra. María de la Luz Galván Ramírez. Centro de Investigación en Enfermedades Tropicales de la Universidad de Guadalajara. Lago Camecuaro no 2398 Colonia Lagos del Country. C.P. 44177. Guadalajara, Jalisco, México.

Telefax: (52) (3) 617-9934 y 617-9935.

Recebido para publicação em 09/06/97. 
Toxoplasma gondii is an obligate intracellular protozoan that causes chronic and acute forms of toxoplasmosis. Epidemiological studies indicates that $20 \%$ to $90 \%$ of adult population worldwide have been in contact with the parasite. The congenital infection is the most severe form of the disease, causing irreversible damage to the nervous system of the fetus, or abortion in pregnant women8 16 .

There are several proteic antigens obtain from Toxoplasma gondii that are recognized by antibodies from patients with some of the forms of toxoplasmosis1261314151822 24, but none of the antigens, have been clearly identified which have the characteristics of a marker for acute or chronic toxoplasmosis.

Recently, several methods have been developed in order to detect seropositive subjects, not only with epidemiologic, but with diagnostic and prognostic purposes. Western Blot technique have been used in order to discriminate subjects with the chronic infection from subjects with the acute form of the disease 45791320 but without conclusive results 513

Here we report, using the tachyzoite stage antigen extract from Toxoplasma gondii in polyacrilamyde gel electrophoresis (SDS-PAGE) and Western Blot technique, the presence of antigenic markers for acute and chronic forms of toxoplasmosis, using the frequency analysis described by Larralde 10 .

\section{MATERIAL AND METHODS}

Subjects (Sera). We study forty-nine female patients, between 18-42 years old, from the Hospital of Obstetrics and Gynecology of the Mexican Social Security Institute at Guadalajara; Jalisco, Mexico. Twenty of them, were adult patients with acute toxoplasmosis and twentynine were adult patients with chronic toxoplasmosis. 20 normal subjects were used as the control group. The three groups: chronic, acute and subjects normal were accurately classified by criteria universally accepted8; such as the presence of lymphadenopathy for acute toxoplasmosis patients, or retinochoroiditis for chronic patients. Also we consider the presence of IgG antibodies for chronic patients and high titer of IgM antibodies for acute patients, by indirect immunofluorescence technic. All sera were divided in three parts and frozen at $-20^{\circ} \mathrm{C}$ until used.

Preparation of Toxoplasma antigen. The strain of Toxoplasma gondii used in this study was the
"RH" (Sabin, 1941); maintained by serial passage every 2 days in the peritoneal cavity of $\mathrm{Balb} / \mathrm{C}$ mice (donated in the Institute of Biomedical Research of the Autonomous University of México, A.P. 70228, 04510 México, D.F. by Doctor Saavedra). Tachyzoites were obtained from the peritoneal cavity of the mice and placed in phosphate-buffer saline, $\mathrm{pH} 7.2$ (PBS), containing heparin $0.1 \%$, finally the pellet was washed in PBS twice.

Contaminated mouse cells were removed by differential centrifugation at $300 \mathrm{~g}$ followed by 3 washes with $0.15 \mathrm{M} \mathrm{NaCl}$ solution. The pellet was suspended in $1 \mathrm{ml}$ of PBS, and stored in $100 \mu \mathrm{l}$ aliquots at $70^{\circ} \mathrm{C} 17$. Protein concentration was determined following Lowry's method 12 .

SDS-PAGE and Western-Blot. The antigen obtained $(1 \mathrm{mg}$ protein $/ \mathrm{ml})$ was mixed in a $1: 2$ dilution with the Laemmli sample buffer (0.02M Tris-HCL pH 6.8, 20\% glycerol, $2 \%$ 2-mercaptoethanol and $0.05 \%$ bromophenolblue), and boiled at $100^{\circ}$ for 5 minutes. The antigen was separated on a vertical slab gel with $15 \%$ acrylamide by electrophoresis technic, at a constant current of $25 \mathrm{~mA}$, in buffer which contained $5 \mathrm{ml} 30 / .88 \%$ acrylamide/bisacrylamide, $1.8 \mathrm{ml}$ of $2 \mathrm{M} 8.8$ Tris-base, $200 \mu \mathrm{l} 10 \%$ sodium dodecilsulfate, $3.1 \mathrm{ml}$ distilled water, $500 \mu$ of $10 \%$ ammonia persulfate, $5 \mu$ l of TEMED.

Markers of molecular weight (Mw), were run in the same gel with bovine serum albumin $(\mathrm{Mw}=69 \mathrm{kDa})$, glyceraldehyde 3-phosphate dehydrogenase $(\mathrm{Mw}=36 \mathrm{kDa})$, carbonic anhydrase $(\mathrm{Mw}=30 \mathrm{kDa})$, trypsinogen inhibitor $(\mathrm{Mw}=21.5 \mathrm{kDa})$ and lactalbumin $(\mathrm{Mw}=14 \mathrm{kDa})$; Sigma Chemical House.

The proteins already separated, were transferred on to a nitrocellulose paper (Transbolt Transfer Medium, Bio-Rad, Richmond CA) using $25 \mathrm{mM}$ Tris-HCL buffer pH 8.2 containing $192 \mathrm{mM}$ glycine and $20 \%(\mathrm{v} / \mathrm{v})$ methanol in an electrophoretic transfer chamber (Bio-Rad) overnight at $0.25 \mathrm{mAmps} 21$. The nitrocellulose strips were soaked for $30 \mathrm{~min}$ in $0.01 \mathrm{M}$ phosphate-buffer saline; containing $0.1 \%(\mathrm{v} / \mathrm{v})$ Tween-20 (PBST), washed and then exposed for $90 \mathrm{~min}$, to $1: 50$ diluted human sera in PBST containing $5 \%$ non-fat dried milk.

After washing two times in PBST, the nitrocellulose strips were incubated for $90 \mathrm{~min}$ with peroxidase-conjugated rabbit anti-human IgG or IgM (DAKO, Copenhagen), diluted 1:1000 in the same buffer. After washing, in the nitrocellulose strips, were developed the bands 
color, with 3,3 diaminobenzidin tetrahydrochloride (DAB, DAKO, Copenhagen), DAB 2.5mg made in $10 \mathrm{ml} \mathrm{PBST}$ plus $\mathrm{CaCl} 1 \%$ with $0.03 \%(\mathrm{v} / \mathrm{v})$ $\mathrm{H}_{2} \mathrm{O}_{2}$. All incubations were carried out at room temperature and the reaction was stopped with $\mathrm{H}_{2} \mathrm{O} 19$.

Immunoplot. A graphic method to measure from 0 to 1 , the frequency of recognition (f) of each band from an individual antigen recognized by specific antibodies in sera of sick and normal subjects through Western Blot thecnic, identifying with these diagnostic markers of crhonic and acute forms. Where $(f)=$ The number of times that a band were recognized was divided with the total number of samples. The proteins candidates for diagnostic markers were considered, when their recognition frequency were $>$ than 0.5 .

The bands recognized in sera from control subjects, were made into graphics according with their frequency (f) on their ordinates $(Y)$, and the bands recognized in sick subjects in the abscissa $(\mathrm{X})$.

Interpretation of the graphic were necessary to rely on the regression line or the quadrants lines with the frequency $>0.5$. The proteins situated near the regression line or in quadrants II and III were considered immunodominate and immunogenic, but they were not useful as diagnostic markers, on the contrary, proteins situated near the $X$ and $Y$ axes, in quadrants $I$ and IV are candidates for diagnostic markers ${ }^{11}$.

\section{RESULTS}

Sera from patients with chronic and acute form of toxoplasmosis were selected by their clinical characteristics plus the presence of specific antibodies against Toxoplasma gondii. This selection help us to investigate the presence of an specific protein in order to differenciate each form of the disease as well as to be used as a diagnostic marker.

Western Blots. Illustrative Western Blots of the Toxoplasma gondii antigens reacting with sera from patients with acute or chronic toxoplasmosis as well as with sera from normal subjects are shown in Figure 1. Twenty sera from acute toxoplasmosis patients recognized 8 bands of molecular weights ranging from 19

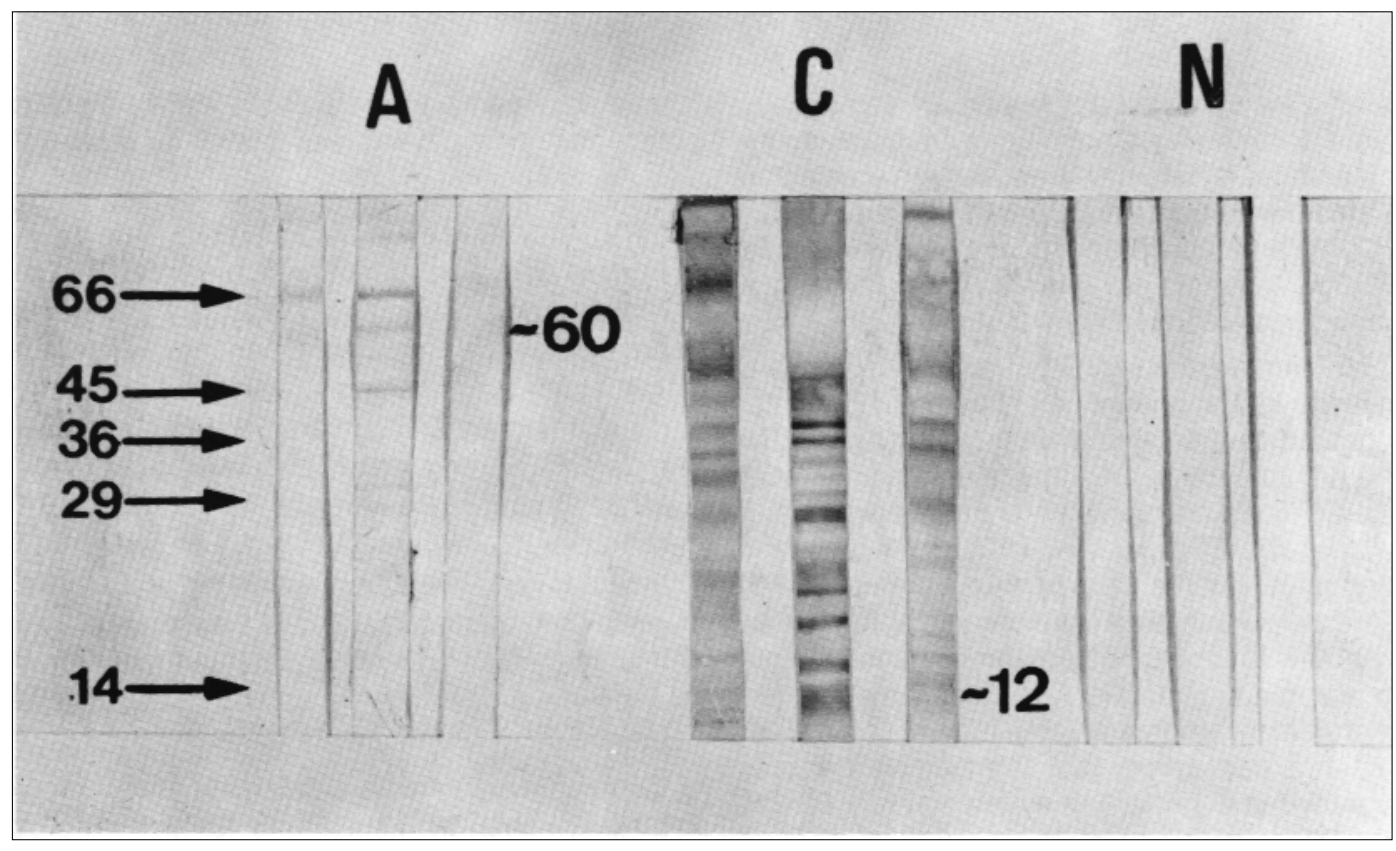

Figure 1 - Western Blot of sera from patients with acute $(A)$ and chronic $(C)$ toxoplasmosis, and normal subjects (N) reacting with Toxoplasma gondii. 
to $90 \mathrm{kDa}$. Twenty-nine sera, from chronic toxoplasmosis subjects, recognized 20 bands from 12 to $90 \mathrm{kDa}$ and finally, sera from normal subjects did not recognize any bands (Table 1).

Table 1 - Molecular weights and frequency of recognition (f) of Toxoplasma gondii antigens by Western Blot toxoplasmosis acute and chronic.

\begin{tabular}{|c|c|c|c|c|}
\hline Proteins kDa & Chronic $\mathrm{n}$. bands & $n=29(f)$ & Acute $\mathrm{n}$ bands & $n=20(f)$ \\
\hline 12 & 20 & 0.68 & & \\
\hline 14 & 11 & 0.37 & & \\
\hline 19 & 7 & 0.24 & 4 & 0.2 \\
\hline 20 & 5 & 0.17 & & \\
\hline 24 & 12 & 0.41 & & \\
\hline 27 & 14 & 0.48 & & \\
\hline 29 & 7 & 0.24 & & \\
\hline 30 & 11 & 0.37 & & \\
\hline 34 & 10 & 0.34 & & \\
\hline 35 & & & 1 & 0.05 \\
\hline 36 & 14 & 0.48 & & \\
\hline 38 & 10 & 0.34 & & \\
\hline 45 & 14 & 0.48 & & \\
\hline 46 & 4 & 0.13 & & \\
\hline 48 & 8 & 0.27 & & \\
\hline 50 & 13 & 0.44 & 2 & 0.1 \\
\hline 60 & & & 12 & 0.60 \\
\hline 66 & 16 & 0.55 & 10 & 0.5 \\
\hline 68 & & & 8 & 0.40 \\
\hline 70 & 13 & 0.44 & 3 & 0.15 \\
\hline 75 & 4 & 0.13 & & \\
\hline 80 & 13 & 0.44 & & \\
\hline 90 & 7 & 0.24 & 4 & 0.2 \\
\hline
\end{tabular}

Immunoplots. The immunoplots of frequencies showed that sera containing IgM from acute toxoplasmosis patients frequently recognized two proteins: one of approximately $60 \mathrm{kDa}$ $(f=0.60)$ and the other of approximately $66 \mathrm{kDa}$ $(f=0.50)$. Normal sera did not recognize any of the antigenic bands (Figure 2A).

The immunoplots of frequencies from sera containing IgG of chronic toxoplasmosis patients, recognized one protein of approximately $12 \mathrm{kDa}$ $(f=0.68)$ and other of apporoximately $66 \mathrm{kDa}$ $(f=0.55)$ and normal sera did not recognized any protein, Figure $2 \mathrm{~B}$. In Figure $2 \mathrm{C}$, the immunoplot results shows the frequencies of data obtained with sera from chronic against sera from acute toxoplasmosis. Sera containing IgG from chronic individuals recognized more often one protein of approximately $12 \mathrm{kDa}(f=0.68)$; while sera containing IgM from acute patients recognized one protein of approximately $60 \mathrm{kDa}$ $(f=0.60)$; other bands were recognized by antibodies presents in both chronic and acute patients but could not be selected as a diagnostic markers since they did not have significant recognition and were less than 0.5 (Table 1).

\section{DISCUSSION}

It is difficult to observe through the WesternBlot method, bands recognized by antibodies present in the sera from patients with chronic and acute toxoplasmosis. Using the immunoplot, described by Larralde in 198911, makes it possible to order the results of the electroimmunotransference in such a way that the complex mix of antigens in general and those of Toxoplasma gondii in particular, can be classified quantitatively and specifically. Thus, this method constitutes a potential tool for bands discrimination, that possess diagnostic and prognostic information.

According with this analysis, three proteins of approximately 12, 60 and $66 \mathrm{kDa}$ were often recognized by the antibodies present in the sera from patients with different states of toxoplasmosis. 

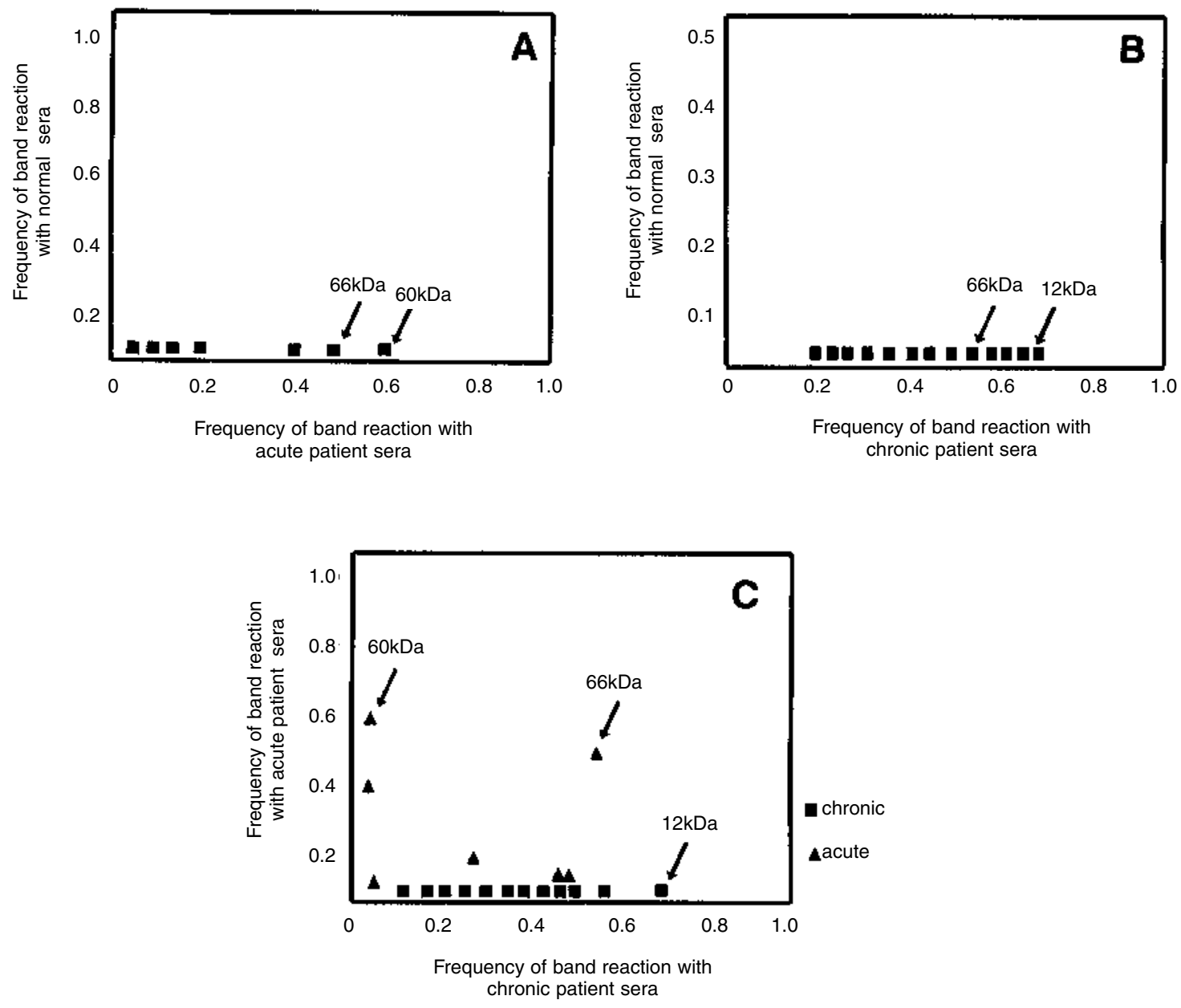

Figure 2 - Immunoplots of (A) acute Toxoplasmosis patients versus normal individuals; $(B)$ chronic versus normal, and (C) acute versus chronic. In (A) it can be observed the approximately $60 \mathrm{kDa}$ and $66 \mathrm{kDa}$ frequently recognized antigens as markers of acute Toxoplasmosis. In (B) it can be observed the approximately $12 \mathrm{kDa}$ and 66kDa frequently recognized antigens as markers of the chronic form of the disease. In (C) it can be observed the above mentioned specific markers for acute and chronic forms and 66kDa protein.

Due to the highest frequency recognition of $60 \mathrm{kDa}$ protein by $\mathrm{IgM}$ antibodies in acute patients, we consider this protein a good marker for this form of infection. Different authors had reported proteins with similar molecular weith recognized by IgM antibodies in patients with the acute form22 23.

In chronic infections the protein of $12 \mathrm{kDa}$ was recognized by the IgG antibodies with a frequency greater than 0.5 . Since this protein was not recognized neither by normal or acute patients, we consider this as a marker protein when Immunoplot method is used.
The presence of the $66 \mathrm{kDa}$ protein in chronic as well as in the acute patients point to this protein as a marker for every persons that have been in contact with Toxoplasma gondii; for the same reason it can not be used as a marker in order to differentiated between the two forms of disease 2.

It's important to mention that with the immunoplot analysis, the proteins recognized with frequencies lower than 0.5 it can't be consider as a diagnostic markers for toxoplasmosis because of their low specificity. 
Although there are other quantitative diagnostic methods for primary toxoplasmosis based in IgG antibodies avidity3; the serologic diagnosis of acute toxoplasmosis can be fortify by the production of monoclonal antibodies, highly specific, against the $60 \mathrm{kDa}$ marker protein and employing simpler methods and less expensive as the ELISA.

Further research is needed to confirm if the proteins of 12 and $60 \mathrm{kDa}$ can be considered as diagnostic markers for the acute and chronic stages of Toxoplasmosis.

\section{ACKNOWLEDGEMENTS}

The authors would like to acknowledge MD Patricia Paredes Casillas for her technical assitence in the preparation of this paper.

\section{REFERENCES}

1. Boulanger F, Bunhomme A, Lebonvallet S, Bummet N, Pluot M. Quantitative immunolocalization of our immunodominant antigens of Toxoplasma gondii. Biology Cellular 73:897, 1991.

2. Decoster A, Darcy F, Capron A. Recognition of Toxoplasma gondii excreted and secreted antigens by human sera from acquired and congenital toxoplasmosis: identification of markers of acute and chronic infection. Clinical Experimental Immunology 73:376-382, 1988.

3. Camargo EM, Da Silva SM, Lesser PG, Granato $\mathrm{CH}$. Avidez de anticorpos IgG específicos como marcadores de infecção primaria recente pelo Toxoplasma gondii. Revista do Instituto de Medicina Tropical de São Paulo 33: 213-218, 1991.

4. Handman E, Goding JW, Remington JS. Detection and characterization of membrane antigens of Toxoplasma gondii. Journal of Immunology 124:778783, 1980.

5. Hassl A, Auer H, Dermetin K, Piucher O, Aspoch H. Experimental studies on circulating antigen of Toxoplasma gondii in intermediate host: criteria for detection and structural properties. Zentralblatt fur Bakteriologie, Mikrobiologie Und Hygiene. Series A, Medical Microbiology, Infection Diseases, Virology Parasitology 263:625-634, 1987.

6. Huskinson J, Thulliez P, Remington JS. Toxoplasma antigens recognized by human immunoglobulin a antibodies. Journal Clinical Microbiology 28:26322636, 1990.

7. Kasper L, Ware PL. Recognition and Characterization of Stage-specific Oocyst/Sporozoite Antigens of Toxoplasma antigens by Human antiserum. Journal Clinical Investigation 75:1570-1577, 1980.
8. Kociecka W, Mrozewicz B, Simon E, Pakula M. Clinical criteria and evaluation of the pathology and progress of lympho-nodular toxoplasmosis. WiadParazytol 36:99-119, 1990.

9. Koch G, Wohlfahrth A, Muller WA. Detection of antibodies against Toxoplasma gondii in human sera in immunoblot procedures. Z-Gesamte-Hygiene 36:555-558, 1990.

10. Laemmli U.K. Cleavage of structural proteins during the assembly of the head of bacteriophage T4. Nature 227:680-685, 1970.

11. Larralde C, Montoya RM, Sciutto E, Diaz ML, Govezensky T, Coltorti E. Decidhering Western Blots of Tapeworm Antigens (Taenia Solium, Echinococcus Granulosus and Taenia Crassiceps) reacting with sera from Neurocysticercosis and Hydatid Disease patients. American Journal of Tropical Medicine and Hygiene 40:282-290, 1989.

12. Lowry OH, Rosebeoungh NJ, Farr AL, Randal RJ. Protein measurement with the Folin Phenol reagent. Journal Biology Chemistry 193:265, 1951.

13. Moir IL, Davison M, D.O. Ho-Yen. Comparation of IgG antibody profiles by immunoblotting in patients with acute and previous Toxoplasma gondii infection. Journal Clinical Pathology 44:569-572, 1991.

14. Partanen P, Turunen JH, Turunen J, Paasivuo R, Forsblom E, Suni J, Leninikki PO. Identification of antigens components of Toxoplasma gondii by immunoblotting technique. Federation of European Biochemnical Societes 158:252-254, 1983.

15. Partanen P, Turunen HJ, Paasivuo RTA, Leninikki PO. Immunoblot Analysis of Toxoplasma gondii antigens by immunoglobulin G, M and $A$ antibodies at different stages infections. Journal Clinical Microbiology 20:133-135, 1984.

16. Remington JS, Desmonts G. Toxoplasmosis In: Remington JS, Klein JO (eds) Infectious diseases of the infant, Saunders, Philadephia p.243-249, 1980.

17. Saavedra R, Demeuter F, Decourt JL, Herion P. Human T-cell clone identifies a potentially protective $54 \mathrm{kDa}$ protein antigen of Toxoplasma gondii cloned and expressed in Escherichia coli. Journal Immunology 147: 1975-1982, 1991.

18. Sharma SD, Mullenax J, Araujo FG, Erilich HA, Remington JS. Western blot Analysis of the Antigens of Toxoplasma gondii recognized by human IgM and IgG antibodies. Journal of Immunology 2:977-983, 1983.

19. Scott DI. Immunoblotting and dot blotting. Journal of Immunological Methods. 119:153-187, 1989.

20. Suzuki Y, Thulliez F, Desmonts G, Reminton JS. Antigen(s) responsible immunoglobulin G Responses 
specific for the acute stage of toxoplasmosis in humans. Journal Clinical Microbiology 28:1734-1738, 1990

21. Towbin H, Staehlin T, Gordon J. Electrophoretic transfer of proteins from polyacrilamide gel to nitrocellulose sheets: Procedure and some applications. Biochemistry 6:4350-4354, 1979.

22. Verhofstede C, Van Gelder P, Rabaey M. Evaluation of immunoblotting for the detection of Toxoplasma gondii immunoglobulin $\mathrm{M}$ antibodies. European Journal
Clinical Microbiology Infection Diseases 9:835-837, 1990.

23. Woodinson G, Smith JE. Identification of the dominant cyst antigens of Toxoplasma gondii. Parasitology 100:389-392, 1990.

24. Zotti C, Maiello A, Moiraghi RA, Sacro T, Parusso R, Ferrero L,Barale A. Reactivity of antigenic fractions obtained from Toxoplasma gondii evaluated with Western blotting. Bulletin Delé Istituto Sieroterapico Milanese 68:167-173, 1989. 